\title{
Plankton community structure and role of Oithona similis on the western coast of Greenland during the winter-spring transition
}

\author{
Sara Zamora-Terol ${ }^{1, *}$, Torkel Gissel Nielsen ${ }^{2,3}$, Enric Saiz ${ }^{1}$ \\ ${ }^{1}$ Institut de Ciències del Mar — CSIC, Barcelona 08003, Spain \\ ${ }^{2}$ National Institute of Aquatic Resources, DTU Aqua, Section for Oceanography and Climate, \\ Technical University of Denmark (DTU), Charlottenlund 2920, Denmark \\ ${ }^{3}$ Greenland Climate Research Centre, Greenland Institute of Natural Resources, Nuuk 3900, Greenland
}

\begin{abstract}
The cyclopoid copepod Oithona similis is one of the most abundant copepods in the oceans and has a potentially important role in pelagic food webs. However, there is a lack of knowledge on aspects of its biology and function in planktonic communities. In the present study, we aimed to assess and compare the species' trophic role in Greenlandic coastal waters during the winter-spring transition, with a focus on its winter behaviour, when large calanoids are not present in the surface layer. Two locations were studied: waters offshore from Godthåbsfjord (Nuuk) in winter, and Qeqertarsuaq (Disko Bay) in spring (bloom and post-bloom period). The potential prey of adult females of $O$. similis was quantified, and grazing experiments were conducted to determine the feeding rates of adult females on phytoplankton and protozooplankton $>10 \mu \mathrm{m}$. The abundance, stage composition, and egg production of $O$. similis was also investigated. Ciliates were the preferred prey for $O$. similis, which confirms its importance as a link between the microbial food web and higher trophic levels. We observed high egg production rates and efficiencies of $O$. similis in winter, confirming that it is active and successfully reproductive in food-limited winter conditions. Our results stress that $O$. similis is a key component of Arctic and subarctic marine communities throughout the year.
\end{abstract}

KEY WORDS: Oithona similis · Trophic role $\cdot$ Egg production $\cdot$ Greenland $\cdot$ Winter $\cdot$ Bloom $\cdot$ Arctic

\section{INTRODUCTION}

Most studies on copepods carried out in Arctic and subarctic seas have focused on large calanoid species, such as Calanus spp. This is mainly due to their high contribution to the copepod biomass relative to smaller species but is also conditioned by the historical undersampling of small copepods due to use of coarse $(>200 \mu \mathrm{m})$ plankton nets (Gallienne \& Robins 2001). Recent investigations, however, have shown the relevance of small copepods in the Arctic (Auel \& Hagen 2002, Hopcroft et al. 2005, Svensen et al. 2011). Despite their size, these copepods are impor- tant in terms of abundance, biomass, and production, especially in coastal waters and fjord systems of the northern hemisphere (Nielsen \& Andersen 2002, Lischka \& Hagen 2005, Arendt et al. 2010). From an abundance point of view, small copepods often outnumber larger species (Møller et al. 2006, Madsen et al. 2008), and in contrast to large calanoids, which spend winter in diapause (Conover 1988, Conover \& Siferd 1993), small copepods can be present yearround in polar seas (Ward \& Hirst 2007, Dvoretsky \& Dvoretsky 2009a).

Among small copepods, Oithona is the most abundant pelagic zooplankton genus on the western coast 
of Greenland (Head et al. 2003, Thor et al. 2005, Madsen et al. 2008), and within the genus, Oithona similis is a cosmopolitan species. Oithona spp. have been described to have year-round presence (Hansen et al. 2004) and reproductive activity (Nielsen \& Sabatini 1996, Ward \& Hirst 2007), and it has been argued that these copepods can exploit microbial food webs more efficiently than calanoid copepods (Nielsen \& Sabatini 1996), characteristics that make Oithona spp. populations more stable in time and space than those of calanoid copepods (Paffenhöfer 1993). Consequently, Oithona spp. could be important food sources for fish larvae and larger zooplankton, especially in those periods of the year when other potential prey are not available.

Regarding Arctic marine environments, only few studies on the biology of Oithona spp. have been published (Nielsen et al. 2002, Ward \& Hirst 2007, Madsen et al. 2008, Narcy et al. 2009), and even less is known about their feeding ecology. It has been reported that Oithona similis prefer motile prey, especially ciliates (Nakamura \& Turner 1997, Lonsdale et al. 2000, Castellani et al. 2005a), although many aspects of their natural diet are still unknown. Thus, our knowledge on their feeding activity in winter in high-latitude environments is almost nonexistent since most of the studies have focused on more productive periods of the year (Atkinson 1996, Møller et al. 2006) and lower latitudes (Castellani et al. 2005a).

The present study represents the first attempt to investigate the role of Oithona similis on the western coast of Greenland, mainly focusing on aspects of its feeding ecology. For that purpose, we carried out different samplings and feeding experiments from winter to late spring to describe seasonal differences in the role of $O$. similis in the plankton community, with a strong interest in their feeding behaviour in winter. Additionally, other aspects of $O$. similis biology and ecology (egg production and population structure) were investigated during the period, and the microplankton and copepod communities were described.

\section{MATERIALS AND METHODS}

\section{Study sites and sampling}

Sampling for the present study took place in 2 areas located at different latitudes on the west coast of Greenland (Fig. 1) in waters offshore from Godthåbsfjord (Nuuk) and Qeqertarsuaq (Disko Bay).

\section{Waters offshore from Godthåbsfjord}

In Godthåbsfjord, the study was conducted at a $350 \mathrm{~m}$ deep station located at the entrance of the fjord $\left(64^{\circ} 07^{\prime} \mathrm{N}, 51^{\circ} 53^{\prime} \mathrm{W}\right)$ (Fig. 1), a dynamic area (Mortensen et al. 2011) that represents the transition zone between the fjord and the marine system at Fyllas Banke, which is never covered by sea ice. Samples were collected from the small boat 'Erisaalik' (Greenland Institute of Natural Resources) in the daytime (09:00 to $15: 00 \mathrm{~h})$ from 16 February to 29 March. Vertical profiles of water temperature, fluorescence, salinity, and density were measured down to $340 \mathrm{~m}$ using a CTD (SBE19plus, SeaCat) equipped with a Seapoint chlorophyll a fluorometer and a Biospherical/Licor sensor. Water samples for chlorophyll a analyses and for estimation of vertical profile of microplankton were taken from 4 depths $(1,15,50$, and $100 \mathrm{~m}$ depth) using a $10 \mathrm{l}$ Niskin water sampler.

\section{Disko Bay}

Sampling in Disko Bay took place at a $250 \mathrm{~m}$ deep station $\left(69^{\circ} 15^{\prime} \mathrm{N}, 5^{\circ} 33^{\prime} \mathrm{W}\right)$ (Fig. 1) from 16 April to 24 May, once the sea ice had broken up. The samples were collected from the RV 'Porsild' (Arctic Station, University of Copenhagen) from

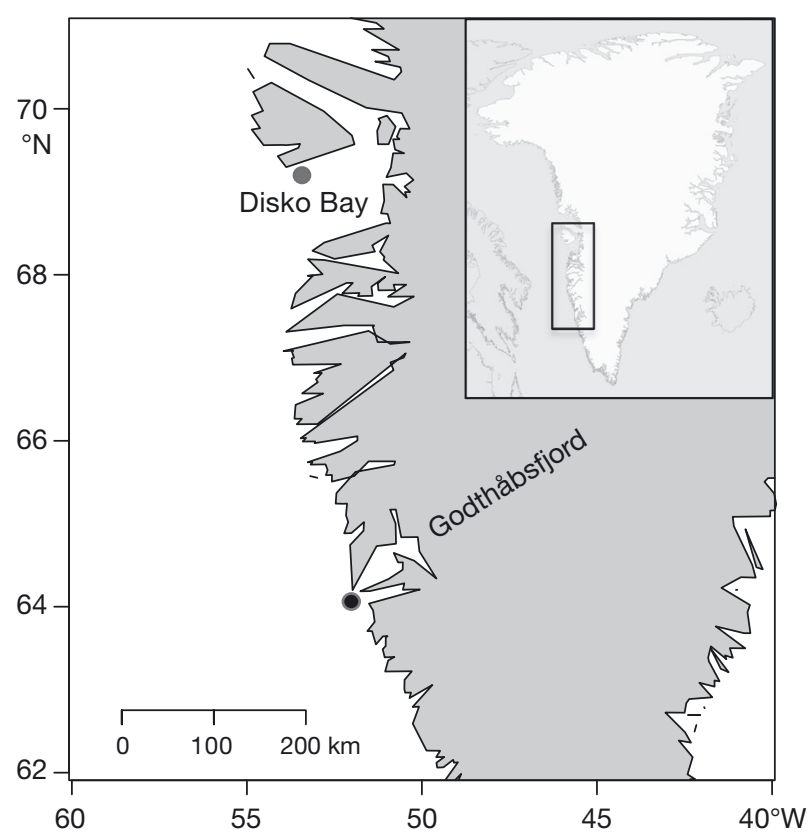

Fig. 1. Map showing sampling stations on the west coast of Greenland, one located at the entrance of the Godthåbsfjord, in Nuuk, and the other site situated $\sim 2 \mathrm{~km}$ off Qeqertarsuaq, in Disko Bay 
09:00 to $14: 00 \mathrm{~h}$. Vertical profiles of salinity, temperature, and fluorescence were taken at each sampling occasion using a Seabird SBE25-01 CTD probe, equipped with a fluorometer. Fluorescence was calibrated against chlorophyll a concentrations determined spectrophotometrically in water samples taken at 8 depths $(1,20,50,75,100,150,200$, and $250 \mathrm{~m}$ ) with a $10 \mathrm{l}$ Niskin water sampler. In addition, samples for determining the vertical profile of microplankton were taken from 4 depths ( 1 , 15,50 , and $100 \mathrm{~m}$ ).

\section{Phyto- and protozooplankton}

Samples taken for chlorophyll a determination (1000 $\mathrm{ml}$ in Godthåbsfjord and $250 \mathrm{ml}$ in Disko) were filtered onto GF/F filters and kept frozen $\left(-18^{\circ} \mathrm{C}\right)$. Later, the filters were extracted in $96 \%$ ethanol for $18 \mathrm{~h}$, and fluorescence was then measured using a fluorometer (TD-700, Turner Designs) calibrated against a pure chlorophyll a standard.

Microplankton samples were fixed with acid Lugol's solution ( $2 \%$ final concentration), settled (from 50 to $1500 \mathrm{ml}$ depending on the in situ concentration), and counted under an inverted microscope. Diatoms, dinoflagellates, and ciliates $(>10 \mu \mathrm{m})$ were identified and classified into $10 \mu \mathrm{m}$ size classes. Microplankton biovolumes were determined from their linear dimensions and volume equations for appropriate geometric shapes (Hillebrand et al. 1999, Olenina et al. 2006) and finally converted into carbon biomass according to the equations provided by Menden-Deuer \& Lessard (2000).

\section{Zooplankton}

Zooplankton samples for taxonomic and quantitative purposes were collected by vertical hauls using a $45 \mu \mathrm{m}$ WP-2 closing net (56 cm diameter) equipped with a flowmeter in Godthåbsfjord and with a $50 \mu \mathrm{m}$ Hydrobios type midi (net opening $50 \mathrm{~cm} \times 50 \mathrm{~cm}$ ) equipped with a flowmeter in Disko. In Godthåbsfjord, the samples were collected above $300 \mathrm{~m}(0-50$, 50-100, 100-200, and 200-300 m), whereas sampling was slightly shallower in Disko (0-50, 50-150, 150200, and 200-250 m). The samples collected for zooplankton analysis were preserved in $4 \%$ buffered formaldehyde (final concentration).

All copepods were identified, with a special focus on Oithona spp. naupliar and copepodite composition. The abundance of females with and without egg sacs was quantified for $O$. similis, and the average number of eggs per sac was determined $(n=10)$. The carbon content of Oithona spp. nauplii and copepodites was calculated using the length-weight regression given by Sabatini \& Kiørboe (1994).

\section{Feeding experiments}

Copepods for feeding experiments were collected from the upper 50 to $100 \mathrm{~m}$ using a $50 \mu \mathrm{m}$ WP-2 net fitted with a large non-filtering cod end. Water for incubation was collected from the depth of maximum fluorescence using a Niskin bottle. A nutrient mixture $\left(15 \mu \mathrm{M} \mathrm{NH}_{4} \mathrm{Cl}\right.$ and $\left.1 \mu \mathrm{M} \mathrm{Na}_{2} \mathrm{HPO}_{4}\right)$ was added to the seawater used in the experiments to compensate for nutrient enrichment due to copepod excretion (Saiz et al. 2013). Adult females of Oithona similis were sorted in ice-chilled petri dishes under a stereomicroscope, washed out in filtered seawater, and transferred to polycarbonate bottles previously filled up with the collected seawater (Godthåbsfjord: $2000 \mathrm{ml}$ bottles, 28 to 35 females per bottle; Disko: $600 \mathrm{ml}$ bottles, 9 to 15 females per bottle). The bottles were completely filled, plastic film was put over the mouth, and the bottles were then placed on a plankton wheel and incubated in a temperature-controlled cold room at light and temperature conditions close to those in situ. At least 3 experimental (with copepods) and 3 control (without copepods) bottles were prepared in each experiment and incubated; in addition, 2 initial bottles (control at Time 0) were immediately preserved with acid Lugol's ( $2 \%$ final concentration) at the beginning of the experiment to obtain initial prey concentrations.

Experiments were run for $\sim 24 \mathrm{~h}$, and the survival of the females was checked under a stereomicroscope at the end of the incubation. At least 15 females were preserved in $4 \%$ formaldehyde (final concentration) for later sizing and estimation of carbon content. Control and experimental bottles were fixed with acid Lugol's and kept in a dark room at $4^{\circ} \mathrm{C}$ until analysis. The identification and counting of the Lugol's samples (initial, control, and experimental) were conducted in the same way as for the vertical profile (see 'Zooplankton').

Clearance and ingestion rates of Oithona similis were calculated according to Frost's equations (Frost 1972) after verification that the prey growth rates in experimental bottles were significantly different than those in the control bottles ( $t$-test, $\mathrm{p}<0.05)$. Weightspecific rates were estimated using our measurements of the size of the potential prey (i.e. diatoms, 
dinoflagellates, and ciliates) and the adult females of $O$. similis and then converted into carbon using carbon content-size relationships from the literature (see 'Zooplankton'). To determine possible size preferences in the diet of $O$. similis, the different groups of protozooplankton were pooled into size classes of $10 \mu \mathrm{m}$ intervals $(10-20,20-30,30-40$, and $>40 \mu \mathrm{m})$, and clearance rates were then calculated for each size class of ciliates and dinoflagellates.

\section{Egg production measurements}

The abundance of ovigerous females in the population was estimated for each depth strata by the sum of attached and detached egg sacs divided by 2 (assuming that all ovigerous females had 2 egg sacs). The percentage of ovigerous females at each sampling day was then calculated as the quotient of the estimated abundance of ovigerous females with respect to the total number of females. The abundance of eggs was calculated by multiplying the number of egg sacs by the average number of eggs per sac.

Egg production rates (EPR, eggs female $\left.{ }^{-1} \mathrm{~d}^{-1}\right)$ were calculated using the egg-ratio method (Edmondson 1971) based on egg and female abundance data from the $4 \%$ formaldehyde fixed samples collected by vertical tows, and the rates were based on the egg hatching time $(H T, \mathrm{~d})$ as follows:

$$
\mathrm{EPR}=\left(\frac{\text { eggs }}{\text { females }}\right) \frac{1}{H T}
$$

The egg hatching time (HT) was calculated using the equation given by Nielsen et al. (2002):

$$
H T=(0.064+0.0145 T)^{-1}
$$

where $T$ is water temperature $\left({ }^{\circ} \mathrm{C}\right)$. Weight-specific egg production was calculated using the egg carbon content that was estimated using the egg volume conversion factor of $0.14 \mathrm{pg} \mathrm{C} \mathrm{mm}^{-3}$ (Kiørboe et al. 1985), and the female carbon content was estimated by the length-weight relationship provided by Sabatini \& Kiørboe (1994). The egg production efficiency (i.e. gross growth efficiency [GGE], \%) of adult females of Oithona similis, i.e. the fraction of ingested food converted into egg production, was calculated as the quotient of weight-specific egg production and ingestion rate and expressed as a percentage.

All of the reproductive parameters were calculated for each depth strata of each sampling day, and then depth-weighted averages were calculated to use in the final estimates of egg production values (i.e. number of ovigerous females, number of eggs, carbon content of the females, and clutch sizes).

\section{RESULTS}

\section{Hydrography}

The monitoring station at the entrance of the Godthåbsfjord system (Fig. 1), sampled during winter conditions, is located in a turbulent area, with strong vertical mixing that is also influenced by the presence of the intense tidal forces in the region (Mortensen et al. 2011). This is corroborated by the CTD profiles which showed a well-mixed water column (Fig. 2), with salinities between 33 and 33.5 and temperatures below $1^{\circ} \mathrm{C}$. The very low chlorophyll a concentrations found (Table 1), with a uniform distribution in the upper $100 \mathrm{~m}$, indicated winter conditions, a situation also confirmed by the low diatom concentrations (Fig. 3).

In Disko Bay, the structure of the water column was completely different during the spring bloom and post-bloom. The area is characterized by the presence of sea ice cover during winter, followed by the ice breakup together with the influence of glacier melt water (from Jakobshavn glacier), which results in strong stratification of the water column in spring (Hansen et al. 2012) (see Fig. 2). Once the sea ice breaks up, light enters the water column and

\begin{tabular}{|c|c|c|c|c|c|c|c|c|c|}
\hline \multirow{2}{*}{$\begin{array}{l}\text { Water } \\
\text { depth (m) }\end{array}$} & \multirow[b]{2}{*}{$23 \mathrm{Feb}$} & \multirow{2}{*}{$\begin{array}{l}\text { - Winter } \\
5 \text { March }\end{array}$} & \multirow[b]{2}{*}{29 March } & \multirow[b]{2}{*}{19 April } & \multicolumn{2}{|c|}{ — Spring bloom } & \multirow[b]{2}{*}{10 May } & \multicolumn{2}{|c|}{ _ Post-bloom } \\
\hline & & & & & 26 April & 3 May & & 17 May & 24 May \\
\hline 1 & 0.07 & 0.07 & 0.13 & $8.3 \pm 0.09$ & $20.4 \pm 2.23$ & $12.8 \pm 1.86$ & $10.0 \pm 1.13$ & $5.2 \pm 0.51$ & $0.9 \pm 0.09$ \\
\hline 15 & 0.07 & 0.07 & 0.14 & $6.6 \pm 0.27$ & $17.9 \pm 2.66$ & $14.7 \pm 2.78$ & $9.0 \pm 1.52$ & $8.2 \pm 1.07$ & $1.5 \pm 0.21$ \\
\hline 50 & 0.08 & 0.08 & 0.14 & $0.9 \pm 0.02$ & $5.0 \pm 1.02$ & $1.8 \pm 0.01$ & $4.3 \pm 0.59$ & $8.3 \pm 1.08$ & $2.4 \pm 0.32$ \\
\hline 75 & 0.07 & 0.07 & 0.14 & $0.3 \pm 0.09$ & $1.5 \pm 0.28$ & $0.8 \pm 0.24$ & $1.4 \pm 0.22$ & $1.5 \pm 0.21$ & $1.4 \pm 0.03$ \\
\hline 100 & 0.07 & 0.07 & 0.14 & $0.1 \pm 0.06$ & $0.8 \pm 0.03$ & $0.5 \pm 0.04$ & $0.9 \pm 0.23$ & $0.9 \pm 0.16$ & $1.4 \pm 0.20$ \\
\hline
\end{tabular}

Table 1. Mean ( $\pm 1 \mathrm{SE})$ chlorophyll a concentrations $\left(\mu \mathrm{g}^{-1}\right)$ in the upper $100 \mathrm{~m}$ from each sampling date 

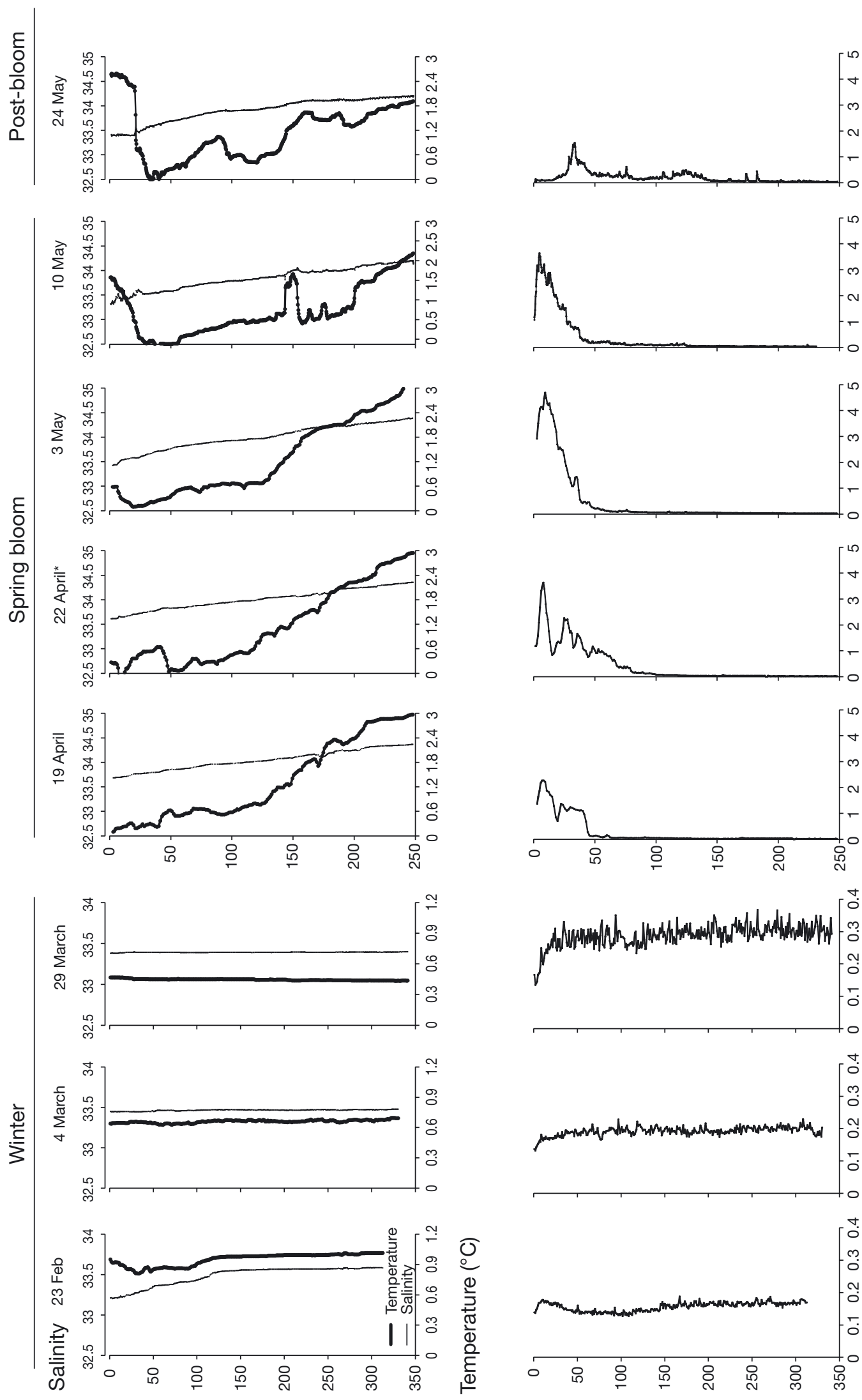

(w) प7də๐

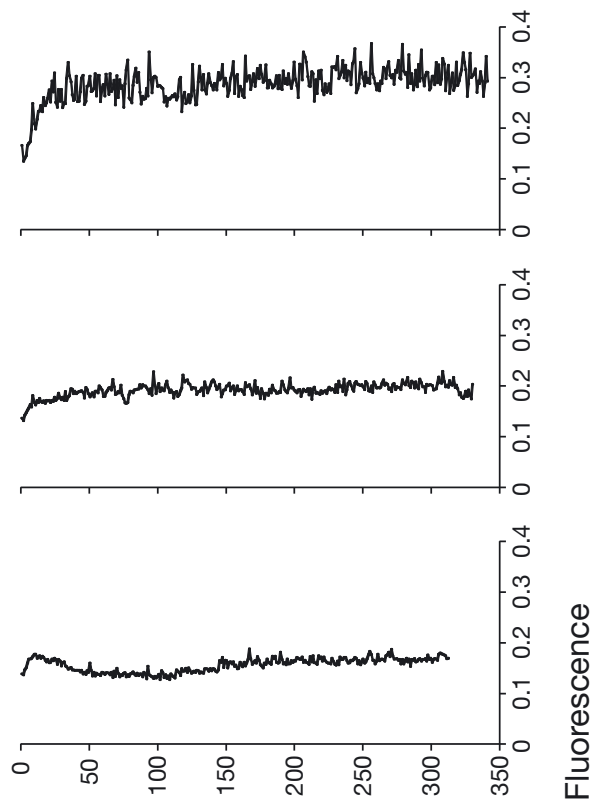

(u) $47 d ə 0$ 

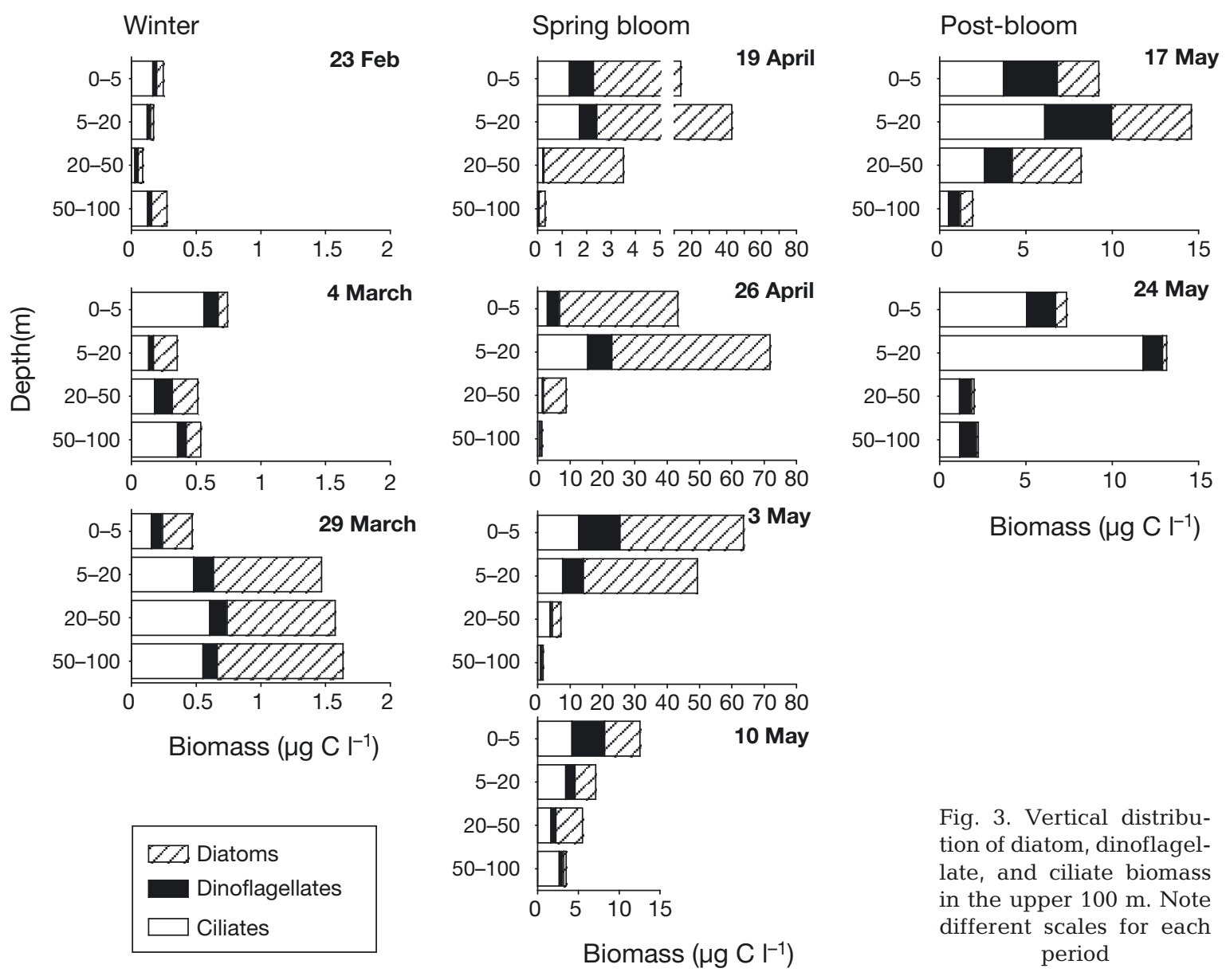

Biomass $\left(\mu \mathrm{g} \mathrm{C}{ }^{-1}\right)$

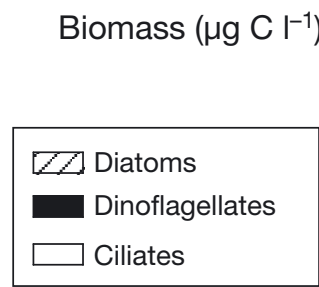

Fig. 3. Vertical distribution of diatom, dinoflagellate, and ciliate biomass in the upper $100 \mathrm{~m}$. Note different scales for each period

triggers the phytoplankton growth (Table 1, Fig. 3). The stratification in the water column was characterized by warmer and more saline water in the bottom during the bloom period (Fig. 2). The temperature of the surface increased by ca. $2^{\circ} \mathrm{C}$, due to the increase of solar heating, creating a more-defined surface thermocline situated at 20 to $30 \mathrm{~m}$ depth during the decaying bloom phase (Fig. 2). Notice that vertical profiles corresponding to 24 April and 17 May are missing in Fig. 2 due to technical problems with the equipment on those sampling dates; for the sake of comparison, a profile from 22 April was added to the figure. The concentration of chlorophyll a observed in Disko Bay illustrated the transition from the beginning of a bloom to a postbloom situation (Table 1, Fig. 2).

\section{Potential prey: phyto- and protozooplankton}

The winter phytoplankton community in the upper $100 \mathrm{~m}$ was dominated by the chain-forming diatoms Chaetoceros spp. and Thalassiosira spp. (on average $92 \%$ of the phytoplankton biomass), with lower densities of Pseudo-nitzschia spp., Navicula spp., Skeletonema spp., and undetermined centric diatoms as well as the silicoflagellate Dictyocha speculum (data not shown). The integrated average biomass of phytoplankton (98\% diatoms) was very low, with values that ranged from 0.03 to $0.65 \mu \mathrm{g} \mathrm{C} \mathrm{l}^{-1}$ corresponding to February and late March, respectively (Table 2). The protozooplankton community was dominated by small (10 to $40 \mu \mathrm{m})$ naked oligotrich ciliates, such as Strombidium spp., Strobilidium spp., and Lohmaniella spp., with Mesodinium spp. present in lower abundances. Tintinnids were either present in low abundances or absent in the samplings. Heterotrophic dinoflagellates were also present, dominated by the athecate genera Gymnodinium and Gyrodinium and with the presence at lower concentrations of thecate dinophysoid and peridinoid dinoflagellates. The integrated average biomass of ciliates ranged from 0.06 to $0.43 \mu \mathrm{g} \mathrm{C} \mathrm{l}^{-1}$, and the corresponding 
Table 2. Mean depth-integrated abundance (cells ml ${ }^{-1}$ ) and biomass $\left(\mu \mathrm{g} \mathrm{Cl}^{-1}\right)$ in the upper $100 \mathrm{~m}$ of each potential prey category (diatoms, dinoflagellates, and ciliates) by sampling location and date

\begin{tabular}{|c|c|c|c|c|c|c|c|c|}
\hline \multirow{2}{*}{ Location } & \multirow{2}{*}{ Date } & \multirow{2}{*}{ Period } & \multicolumn{2}{|c|}{$\longrightarrow$ Diatoms } & \multicolumn{2}{|c|}{ — Dinoflagellates _ } & \multicolumn{2}{|c|}{ Ciliates } \\
\hline & & & 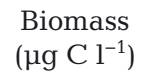 & $\begin{array}{l}\text { Abundance } \\
\left(\text { cells } \mathrm{ml}^{-1} \text { ) }\right.\end{array}$ & $\begin{array}{c}\text { Biomass } \\
\left(\mu g \mathrm{C}^{-1}\right)\end{array}$ & $\begin{array}{l}\text { Abundance } \\
\left(\text { cells } \mathrm{ml}^{-1} \text { ) }\right.\end{array}$ & 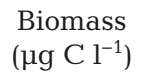 & $\begin{array}{l}\text { Abundance } \\
\left(\text { cells ml }{ }^{-1} \text { ) }\right.\end{array}$ \\
\hline \multirow{3}{*}{$\begin{array}{l}\text { Godthåbs- } \\
\text { fjord }\end{array}$} & 23 February & Winter & 0.03 & 0.14 & 0.02 & 0.07 & 0.06 & 0.06 \\
\hline & $4 \mathrm{March}$ & & 0.14 & 0.51 & 0.08 & 0.13 & 0.18 & 0.15 \\
\hline & 29 March & & 0.65 & 1.63 & 0.11 & 0.17 & 0.43 & 0.38 \\
\hline \multirow[t]{4}{*}{ Disko } & 19 April & Spring & 12.25 & 17.73 & 0.27 & 0.52 & 0.61 & 0.47 \\
\hline & 26 April & bloom & 17.93 & 39.96 & 2.28 & 2.82 & 4.68 & 3.41 \\
\hline & 3 May & & 12.83 & 22.18 & 2.91 & 3.70 & 4.62 & 3.31 \\
\hline & 10 May & & 2.38 & 6.15 & 0.91 & 1.60 & 2.06 & 1.54 \\
\hline \multirow[t]{2}{*}{ Disko } & 17 May & Post- & 3.07 & 5.20 & 1.93 & 4.19 & 2.93 & 3.98 \\
\hline & 24 May & bloom & 0.17 & 0.39 & 0.78 & 2.30 & 3.86 & 9.42 \\
\hline
\end{tabular}

biomass of dinoflagellates ranged from 0.02 to $0.11 \mu \mathrm{g} \mathrm{C}^{-1}$ (Table 2). The vertical distribution of protozooplankton in general mirrored the water column structure (Fig. 3).

During spring, the composition of the phytoplankton community was similar to that found in winter, but the abundances were higher. During the spring bloom, the dominating diatom was Thalassiosira spp., and the small flagellates Phaeocystis spp. were present at high abundance. The integrated average biomass of phytoplankton (excluding Phaeocystis spp.) ranged from 2.4 to $17.9 \mu \mathrm{C}^{-1}$ in the bloom

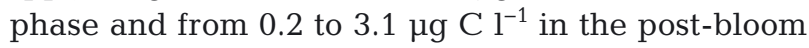
period (Table 2). Ciliates, again, dominated the protozooplankton community during the spring bloom and post-bloom (Fig. 3, Table 2), and the most abundant ciliates and heterotrophic dinoflagellates were similar to those found in winter. The integrated average biomass of ciliates ranged from 0.6 to $4.7 \mu \mathrm{g} \mathrm{Cl}^{-1}$ during the bloom period and from 2.9 to $3.9 \mu \mathrm{g} \mathrm{C}^{-1}$ during the post-bloom phase, whereas for dinoflagellates, the biomass ranged from 0.3 to $2.9 \mu \mathrm{C} \mathrm{Cl}^{-1}$ during the bloom and from 0.8 to $1.9 \mu \mathrm{g} \mathrm{Cl}^{-1}$ in the postbloom phase (Table 2).

The peak abundance and biomass of phytoplankton, dinoflagellates, and ciliates were found in the upper $20 \mathrm{~m}$, with a dominance of diatoms in that depth strata during the early phase of the bloom and a dominance of ciliates later in the decay phase of the bloom (Fig. 3).

\section{The copepod community}

Copepods dominated the mesozooplankton, constituting $71 \%, 94 \%$, and $88 \%$ of the total abundance in the winter, spring-bloom, and post-bloom pe- riods respectively. The abundance in the different depth strata fluctuated from a few tens (winter) to 14000 ind. $\mathrm{m}^{-3}$ (post-bloom period) (Fig. 4) and from a few hundreds to 4000 ind. $\mathrm{m}^{-3}$ (weighted average) for the whole water column.

During winter, the small copepods Microcalanus spp., Microsetella spp., Oithona spp., Oncaea spp., and Pseudocalanus spp. dominated, whereas the larger copepods Calanus spp. and Metridia spp. were less abundant (Fig. 4). Average abundances across depths and dates during winter were 105 ind. $\mathrm{m}^{-3}$ for Microcalanus spp., 120 ind. $\mathrm{m}^{-3}$ for Microsetella spp., 67 ind. $\mathrm{m}^{-3}$ for Oithona spp., and 74 ind. $\mathrm{m}^{-3}$ for Oncaea spp. The group 'others' was composed of much-less-abundant copepod species and other mesozooplankton components (e.g. foraminifera, Thecosomata, and tintinnids), which accounted for 25 to $35 \%$ of the total mesozooplankton community. In winter, Oithona spp. contributed 10 to $15 \%$ to the total mesozooplankton abundance and 15 to $20 \%$ to the copepod abundance. The vertical distribution of the copepod community did not follow any specific pattern, probably due to the strong mixing in that dynamic sampling area (Fig. 4).

During the spring bloom at Disko Bay, the diversity of copepods was similar to that observed in winter at the Godthåbsfjord, but in contrast, larger calanoids dominated the copepod community both in abundance (Fig. 4) and biomass (data not shown). However, during the initial phase of the bloom, small copepods were still very abundant, and Oncaea spp. and Oithona spp. together contributed $>50 \%$ of the total copepod abundance (Fig. 4; 19 April). At the peak of the spring bloom, there was a decrease in the relative abundance of small copepods due to a large increase in the abundance of Calanus spp. (especially nauplii). Calanus species reached their maxi- 

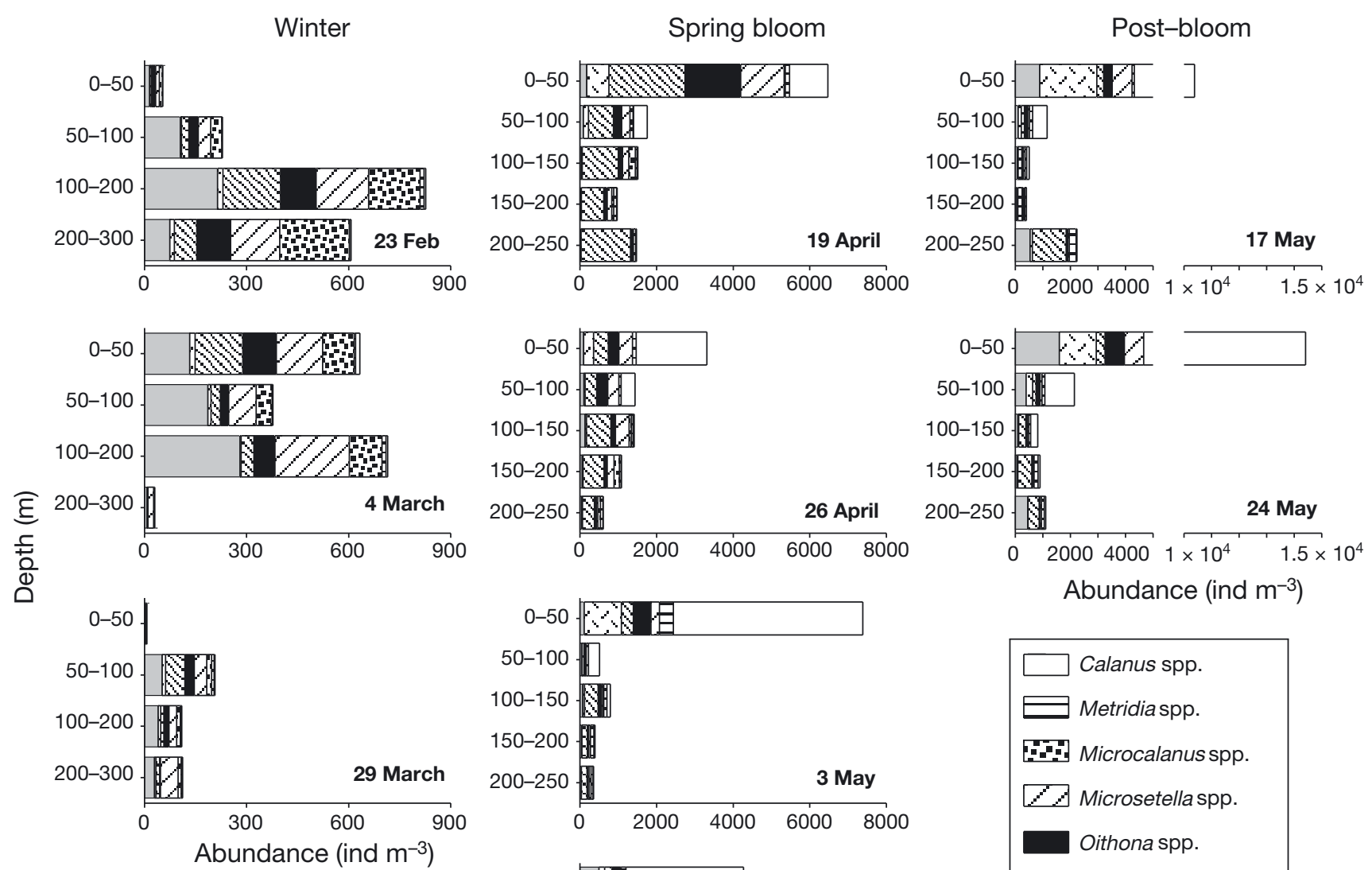

Fig. 4. Vertical distribution of copepod abundance (ind. $\left.\mathrm{m}^{-3}\right)$ in winter $(0-50$, 50-100, 100-200 and 200-300 m depth strata) and in spring $(0-50,50-100$, 100-150, 150-200, 200-250 m depth strata). Each date of sampling is indicated. Note different scales on the $x$-axis
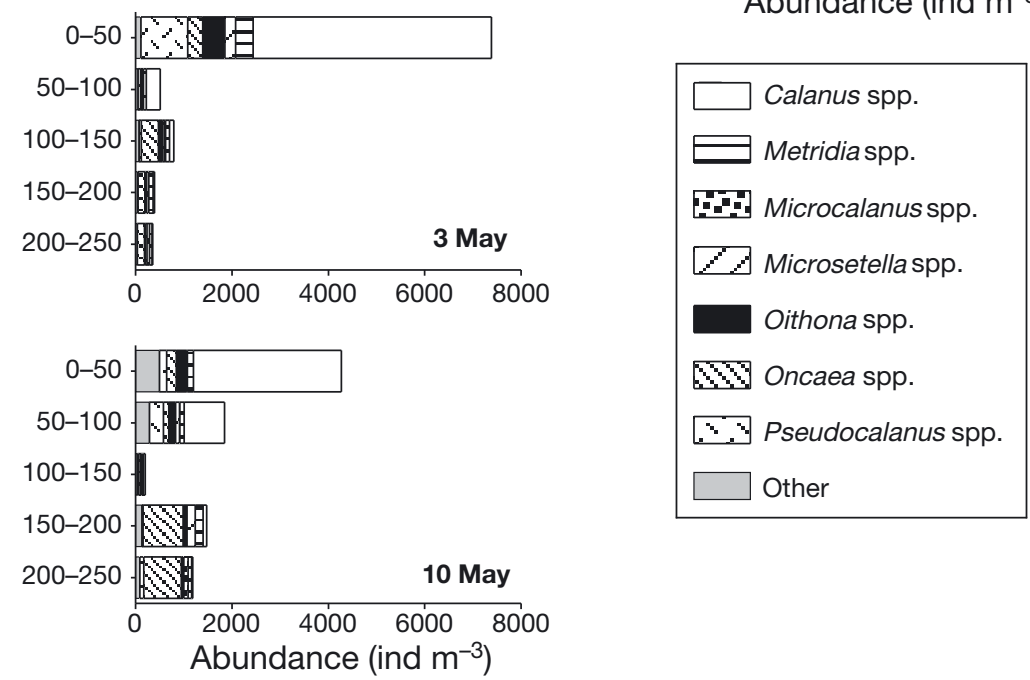

\footnotetext{
cated. Note different scales on the $x$-axis
}

mum abundances in the post-bloom period (Fig. 4). The mean abundance of copepods fluctuated between 1817 ind $\mathrm{m}^{-3}$ during the bloom period and 2982 ind. $\mathrm{m}^{-3}$ during the post-bloom phase (Fig. 4). The maximum abundance of copepods were always located in the upper $50 \mathrm{~m}$, in association with the highest microplankton concentrations (located in the upper $20 \mathrm{~m}$; Fig. 4). Oithona spp. contributed 4 to $15 \%$ of the total mesozooplankton abundance during the spring-bloom and post-bloom periods. The other mesozooplankton groups represented $<10 \%$ in all samplings.

Although some Oithona atlantica were observed in the vertical tows, their abundance was negligible, and therefore, $O$. similis was the target species in the present study. From now on, we will refer to Oithona spp. as Oithona similis.

\section{Oithona similis stage vertical distribution, abundance, and composition}

During winter, the vertical distribution of nauplii and copepodites of Oithona similis showed no clear pattern, although maximum abundances for both stages were found at the same depth strata at each sampling date (Fig. 5). From the beginning to the end of the winter, the abundance (weighted average) of naupliar and copepodite stages of $O$. similis varied from 41 to 7 nauplii $\mathrm{m}^{-3}$ and from 33 to 4 copepodites $\mathrm{m}^{-3}$ (data not shown). During the winter period, the most abundant stage (weighted average over dates) was C5 ( 8 ind. $\left.\mathrm{m}^{-3}\right)$, followed by N3 ( 5 ind. $\left.\mathrm{m}^{-3}\right)$, N5 $\left(\sim 5\right.$ ind $\left.\mathrm{m}^{-3}\right)$, and adult females $\left(\sim 4\right.$ ind. $\left.\mathrm{m}^{-3}\right)$ (data not shown). The relative stage composition was diverse but constant throughout the winter period, 

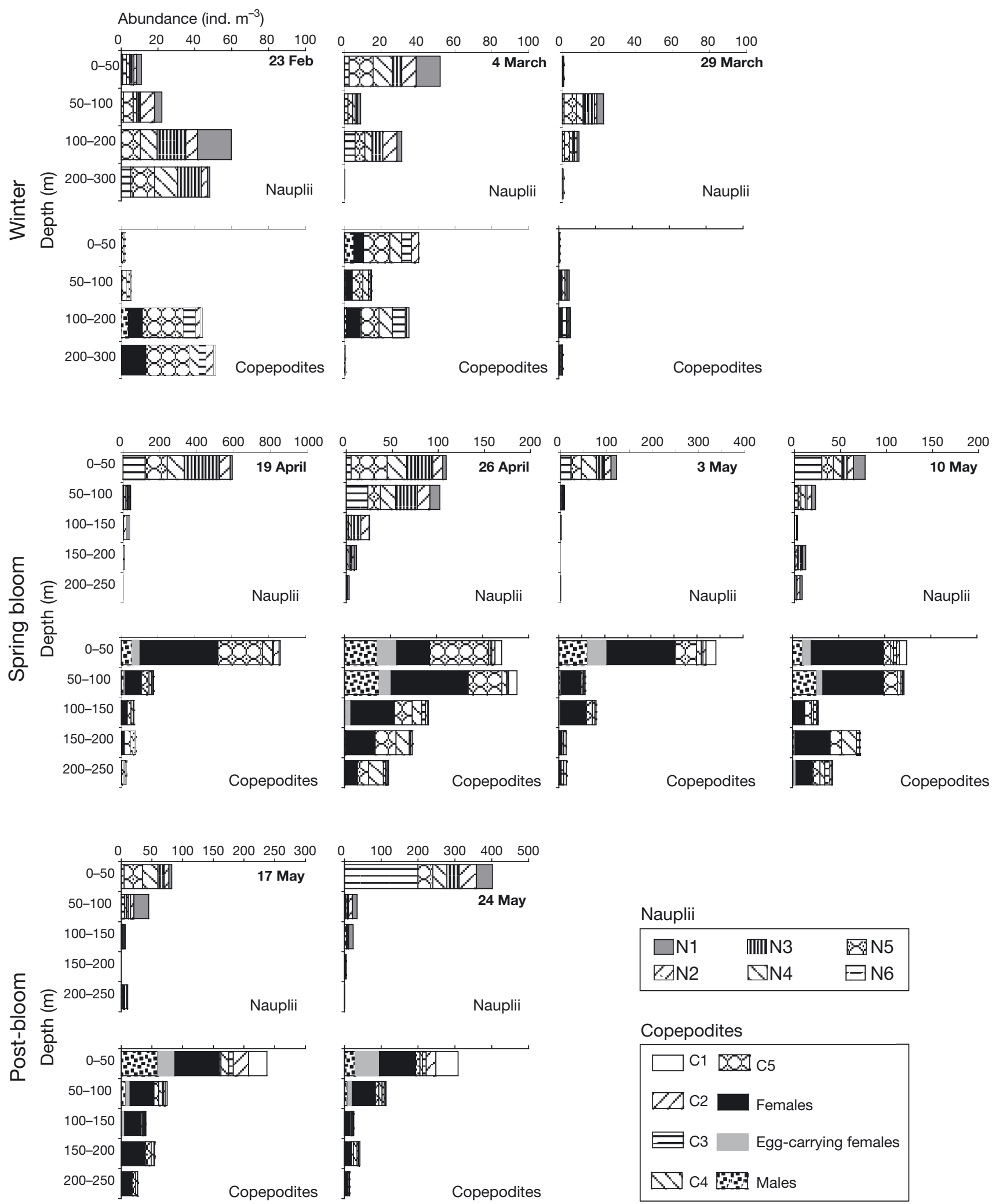

Nauplii
$\begin{array}{|lll|}\square \mathrm{N} 1 & \text { 盂N3 } & \square \mathrm{N} 5 \\ \square \mathrm{N} 2 & \square \mathrm{N} 4 & \square \mathrm{N} 6\end{array}$

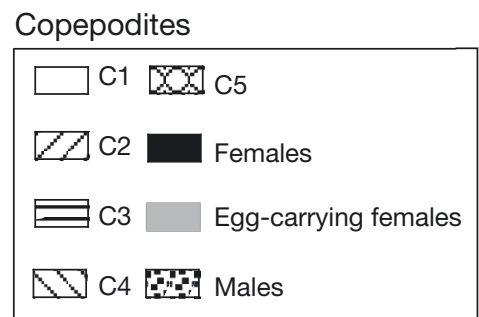

Fig. 5. Oithona similis. Vertical distribution of nauplii and copepodites (ind. $\mathrm{m}^{-3}$ ) during winter, spring bloom, and post-bloom. Depth strata as in Fig. 4 
and both nauplii and copepodites accounted for approximately half of the population at each sampling date, with a slight increase in the contribution of nauplii in the last sampling (Fig. 6). The proportion of adult females was quite stable, representing $\sim 10 \%$ of the population (Fig. 6).

In contrast to the winter in Godthåbsfjord, nauplii and copepodites did not show the same vertical pattern during spring in Disko Bay. Nauplii were mainly located in the upper $50 \mathrm{~m}$, whereas copepodites, although also abundant in the upper layers, were much more abundant in deeper waters (Fig. 5). The abundance of nauplii stages varied among sampling dates with a non-defined trend, although the latest stages (N4 to N6) were most abundant (Fig. 5). Overall, adult females were the most abundant developmental stage with abundances (weighted average) between 46 and 122 ind. $\mathrm{m}^{-3}$ (data not shown) during the spring. Overall, the stage composition of Oithona similis during the spring-bloom and post-bloom periods was dominated by later copepodite stages, with the exception of the last sampling of the post-bloom period, in which the number of nauplii increased, reaching $50 \%$ of the total stage abundance (Fig. 6). During the bloom, the population of $O$. similis became increasingly dominated by adult females, which were by far the most abundant stage and contributed 30 to $46 \%$ of the total abundance of developmental stages (Fig. 6).

\section{Feeding rates and prey selection of Oithona similis}

Ciliates were the most abundant components of the protozooplankton community and the preferred prey for adult females of Oithona similis. There was a significant relationship between ingestion and protozooplankton abundance $(\mathrm{n}=9, \mathrm{p}=0.03$; data not shown). However, the relation was mainly due to the abundance of ciliates, as evidenced when ciliates alone were considered in the feeding rate calculations (Fig. 7, Table 3). Clearance rates on diatoms were always negative (data not shown), and therefore, no feeding rates could be computed.

Clearance rates (average $\pm \mathrm{SE}$ ) on ciliates were inversely correlated to ciliate concentration and ranged from $6 \pm 6.1$ to $51 \pm 12.3 \mathrm{ml}$ female $^{-1} \mathrm{~d}^{-1}$ (Fig. 7A, Table 3). Ingestion rates on ciliates (average

$\pm \mathrm{SE}$ ) ranged from maximum values of $199 \pm 103$ ciliates female $\mathrm{f}^{-1}$ during the spring bloom to minimum values of $9 \pm 1.4$ ciliates female ${ }^{-1} \mathrm{~d}^{-1}$ during winter (Fig. 7B, Table 3). Ingestion rates, in terms of daily rations ( $\%$ body carbon ingested per day), were low in winter $(1.4 \%)$ and reached maximum values of $\sim 20$ to $23 \%$ during the spring bloom (Fig. $7 \mathrm{C}$, Table 3). Feeding rates were positively correlated with ciliate abundance and biomass (Fig. 7B,C).

The highest clearance rates on ciliates were measured when adult females of Oithona similis fed on cells between 20 and $40 \mu \mathrm{m}$ size (equivalent spherical diameter), and such rates reached maximum values $\left(\sim 113 \mathrm{ml}\right.$ female $\left.{ }^{-1} \mathrm{~d}^{-1}\right)$ when feeding on the size range 30-40 $\mu \mathrm{m}$ (Fig. 8A). Ciliates in the 20-40 $\mu \mathrm{m}$ size range mainly comprised Strombidium spp. and Lohmaniella spp. as well as lower numbers of Strobilidium spp.

Overall, results of feeding rates on dinoflagellates were inconclusive, with negative values in some replicates and statistically non-significant values in most of the experiments. The results of feeding rates on dinoflagellates are shown in Table 3 and will be discussed later. Clearance rates on dinoflagellates by sizes tended to be higher on the $10-30 \mu \mathrm{m}$ prey size range (Fig. 8B). In general, for similar-sized prey, ciliates were cleared more efficiently than dinoflagellates (Fig. 8).

\section{Egg production and egg production efficiency}

Egg-carrying females of Oithona similis were present both in winter and spring, with values sur- 

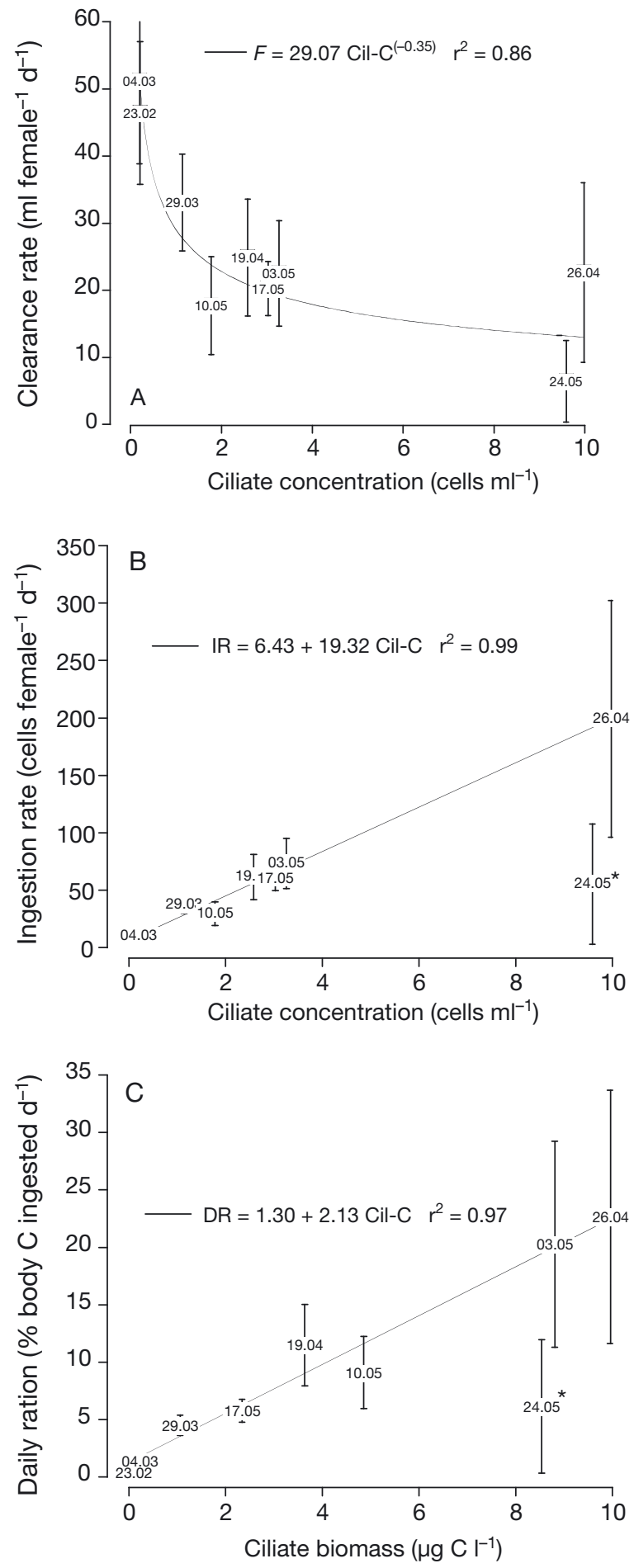

Fig. 7. Oithona similis. Feeding rates of adult females on ciliates. (A) Clearance rate $\left(F, \mathrm{ml}\right.$ female $\left.{ }^{-1} \mathrm{~d}^{-1}\right)$, (B) ingestion rate (IR, cells female $\left.{ }^{-1} \mathrm{~d}^{-1}\right)$, and $(\mathrm{C})$ daily ration $(\mathrm{DR}, \%$ body carbon ingested female $e^{-1} \mathrm{~d}^{-1}$ ). Each point represents the mean value ( $\pm 1 \mathrm{SE})$ of 3 to 4 replicates. Cil-C: ciliate concentration, either in cells or carbon. Asterisks $\left({ }^{*}\right)$ indicates dates not included in the fitted equations due to the presence of negative values

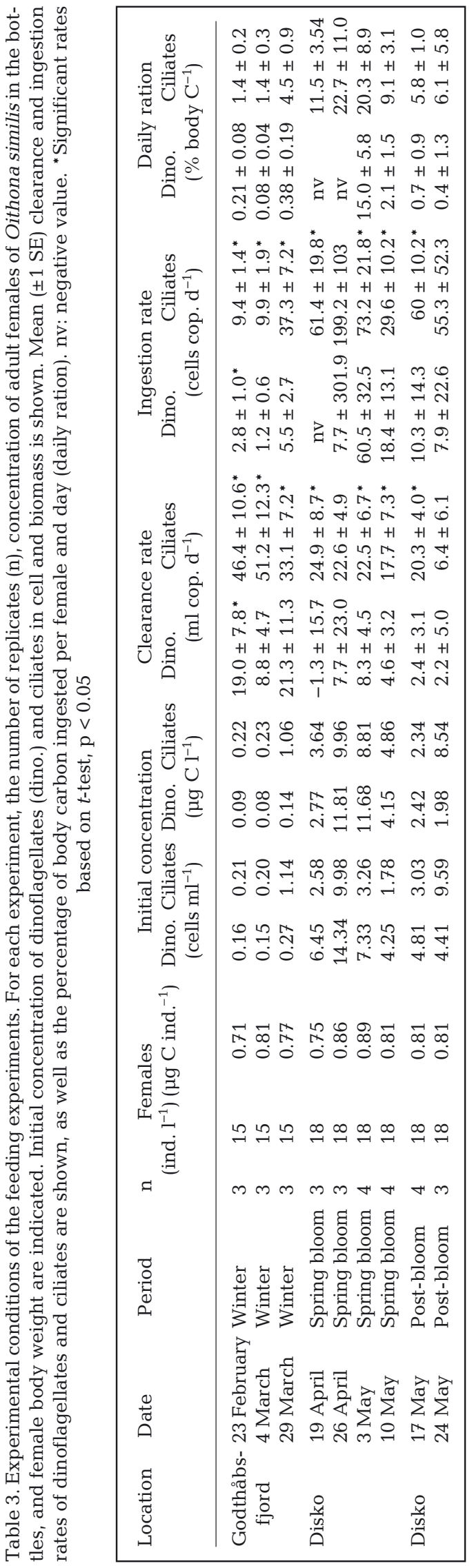



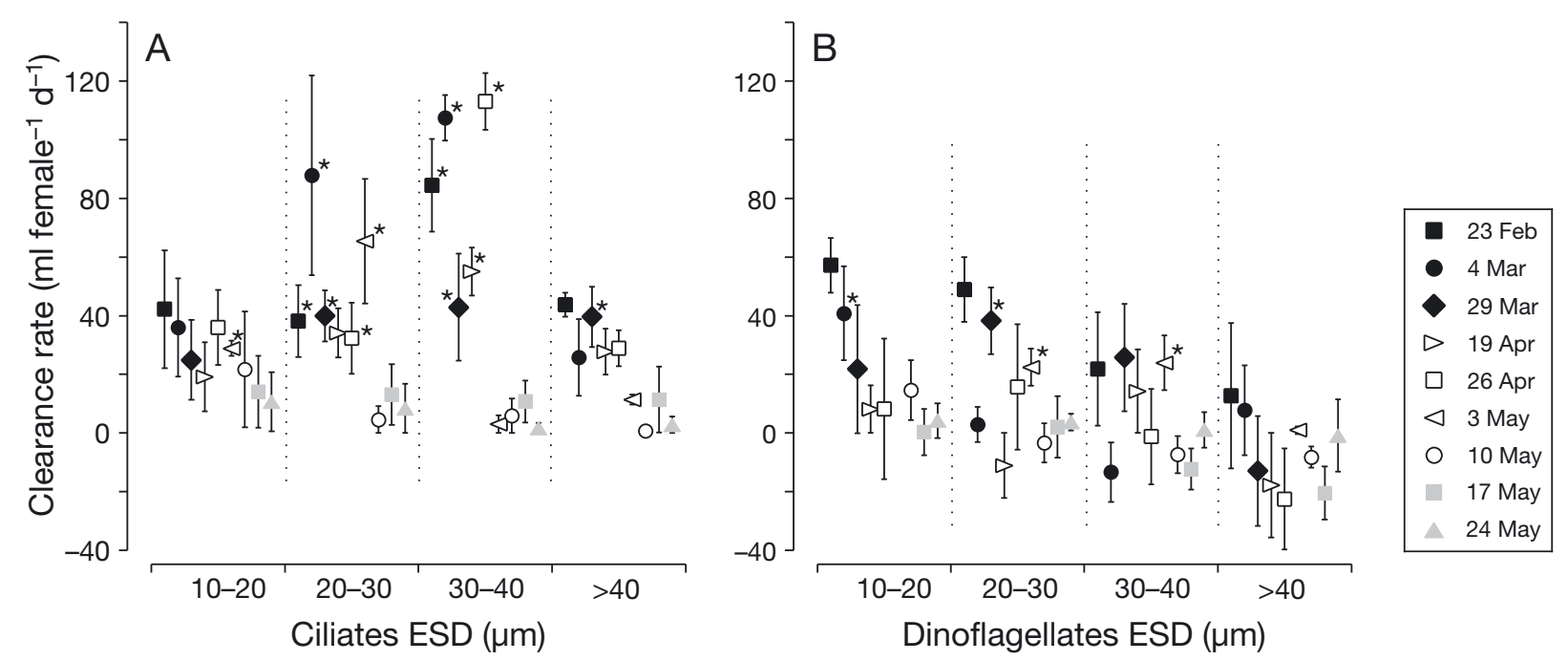

Fig. 8. Oithona similis. Size-dependent clearance rates ( $\mathrm{ml}$ female $\mathrm{f}^{-1} \mathrm{~d}^{-1}$ of adult females on (A) ciliates and (B) dinoflagellates. Symbols in black, white and grey represent winter, spring bloom and post-bloom, respectively. Each point represents the mean value $( \pm 1 \mathrm{SE})$. Asterisks $\left({ }^{*}\right)$ indicate statistically significant grazing rates $(t$-test, $\mathrm{p}<0.05)$

prisingly high in winter when compared with spring, and were most abundant in the post-bloom period (Table 4). The relative abundance of ovigerous females varied from a minimum of $8 \%$ (winter) to a maximum of $56 \%$ (post-bloom) (Table 4). Clutch sizes (eggs female ${ }^{-1}$ ) ranged from 16 to 26 eggs in winter, from 14 to 36 eggs in the spring bloom, and from 14 to 38 eggs in the post-bloom period (Table 4). Mean clutch sizes did not show important differences among the bloom phases and varied on average from 18 (spring bloom) to 22 (post-bloom) eggs per female (Table 4). Variability among average clutch sizes on different sampling dates is reported in Table 4. Egg size did not vary much during the period of the present study, averaging $57 \pm 3 \mu \mathrm{m}(\mathrm{n}=20)$ in diameter.

Mean egg production rates varied from 0.09 (winter and spring bloom) to 0.91 (post-bloom) eggs female ${ }^{-1} \mathrm{~d}^{-1}$, and weight-specific egg production rates varied from $\sim 0.2$ to $2 \% \mathrm{~d}^{-1}$ (Table 4 ). Oithona similis egg production rates (either per capita or weight-specific) were not very variable from winter to the spring bloom, although females found in the tows were slightly smaller in winter (average $0.60 \mu \mathrm{g}$ $\mathrm{C}$ per female) than in spring (average $0.68 \mu \mathrm{g} \mathrm{C}$ ). During the post-bloom period, however, egg production rates increased on average 3.8-fold compared to the rates found in the earlier periods. In contrast, egg production efficiencies were relatively high in winter (on average $23 \%$ ), decreased during the spring bloom $(3 \%)$, and increased again during the postbloom phase $(25 \%)$ (Table 4$)$.

\section{DISCUSSION}

\section{Environmental setting}

The CTD profiles revealed a mixed water column during winter, with homogenous and very low chlorophyll a concentrations in Godthåbsfjord, in contrast to the development of a stratified water column with increasing chlorophyll a during the spring-bloom and post-bloom phases in Disko Bay (Fig. 2). The 2 localities chosen for the present study represented the typical events in the seasonal succession in the oceanography and plankton along western Greenland (Mortensen et al. 2011, Hansen et al. 2012) and can therefore be merged and used to illustrate the winter-spring transition in general. In the present study, the microplankton community of southwestern Greenland was investigated for the first time in winter, showing a clear dominance of ciliates and dinoflagellates. The similar winter importance of protozooplankton in Arctic plankton communities documented further north (Levinsen et al. 2000) enable us to hypothesize that protozooplankton constitute a main food source in the winter diet of copepods in those latitudes.

The winter copepod community described in the present study in the southwest of Greenland was dominated by small copepods, as previously documented in the same area for the late summer (Tang et al. 2011) and for the periods of the year when Calanus spp. are not present in the surface layer in Disko Bay (Madsen et al. 2008). Our study documents 
Table 4. Fecundity of Oithona similis. Proportion of ovigerous females, clutch size, egg production rates (EPR), and weightspecific egg production rates (SEPR) are based on weighted average values from WP-2 net and multinet samples. Egg production efficiencies (GGE) are estimated from weight-specific ingestion rates only on ciliates

\begin{tabular}{|c|c|c|c|c|c|c|c|c|}
\hline \multirow{2}{*}{$\begin{array}{l}\text { Location } \\
\text { Date }\end{array}$} & \multirow[t]{2}{*}{ Period } & \multirow{2}{*}{$\begin{array}{c}\text { Temperature } \\
\left({ }^{\circ} \mathrm{C}\right)\end{array}$} & \multirow{2}{*}{$\begin{array}{c}\text { Ovigerous } \\
\text { females } \\
(\%)\end{array}$} & \multicolumn{2}{|c|}{ Clutch size } & \multirow{2}{*}{$\begin{array}{c}\text { EPR } \\
(\text { eggs } \\
\left.\text { female }^{-1} \mathrm{~d}^{-1}\right)\end{array}$} & \multirow{2}{*}{$\begin{array}{c}\text { SEPR } \\
\left(\% d^{-1}\right)\end{array}$} & \multirow{2}{*}{$\begin{array}{r}\text { GGE } \\
(\%)\end{array}$} \\
\hline & & & & $\begin{array}{c}\text { (eggs } \\
\text { female }^{-1} \text { ) }\end{array}$ & $\begin{array}{l}\text { Average and } \\
\text { range }\end{array}$ & & & \\
\hline \multicolumn{9}{|l|}{ Godthåbsfjord } \\
\hline 23 February & Winter & 1.0 & 8 & $16.3 \pm 0.33^{\mathrm{a}}$ & $20(16-23)$ & 0.09 & 0.2 & 16 \\
\hline 4 March & Winter & 0.7 & 24 & $19.7 \pm 0.93^{\mathrm{a}}$ & & 0.30 & 0.7 & 47 \\
\hline 29 March & Winter & 0.4 & 14 & $23.9 \pm 1.22^{\mathrm{a}}$ & & 0.17 & 0.4 & 9 \\
\hline \multicolumn{9}{|l|}{ Disko } \\
\hline 19 April & Spring bloom & 0.3 & 15 & $15.9 \pm 1.53$ & $18(14-36)$ & 0.17 & 0.4 & 3 \\
\hline 26 April & Spring bloom & $0.4^{\mathrm{b}}$ & 29 & $17.7 \pm 0.39$ & & 0.19 & 0.4 & 2 \\
\hline 3 May & Spring bloom & 0.2 & 12 & $18.7 \pm 0.10$ & & 0.09 & 0.2 & 1 \\
\hline 10 May & Spring bloom & 1.0 & 31 & $20.5 \pm 0.56$ & & 0.30 & 0.7 & 7 \\
\hline \multicolumn{9}{|l|}{ Disko } \\
\hline 17 May & Post-bloom & $1.5^{\mathrm{b}}$ & 36 & $20.1 \pm 1.18$ & $22(14-38)$ & 0.51 & 1.1 & 20 \\
\hline 24 May & Post-bloom & 2.3 & 56 & $23.2 \pm 0.94$ & & 0.91 & 1.9 & 31 \\
\hline
\end{tabular}

the abundance of small copepods in winter, suggesting they comprise an important food web component, often unconsidered, outside the period of the main bloom. The even vertical distribution of different species of copepods found in winter could be explained by the turbulent regime in the area (Mortensen et al. 2011), which could blur the 'natural' distribution patterns of species separated vertically in less-energetic systems (Haury et al. 1990). However, during the spring bloom and post-bloom period, when Calanus spp. took over the surface water, the smaller copepods were more abundant in deeper waters.

\section{Population dynamics of Oithona similis}

Even though it is one of the most abundant copepods in Arctic and subarctic regions (Auel \& Hagen 2002, Hopcroft et al. 2005, Møller et al. 2006, Madsen et al. 2008, Svensen et al. 2011), the population dynamics of Oithona similis have not been investigated thoroughly in Greenland. In the present study, we found all developmental stages of $O$. similis present during the period of sampling. The presence of egg-carrying females during winter confirmed the year-round reproduction strategy described for $O$. similis from lower latitudes (Kiørboe \& Nielsen 1994, Sabatini \& Kiørboe 1994). Moreover, the presence of the earliest nauplii stages in winter evidenced a successful recruitment despite unfavourable food conditions. In spring, $O$. similis females were present in the entire water column, but the younger stages were mostly found near the surface. We observed an increase in nauplii abundance by the end of May (post-bloom) parallel to an increase in ovigerous female abundance, indicating that the peak production of $O$. similis must occur later in the season. The eggs produced by females late in the period will form the basis of the high abundance of $O$. similis normally observed in summer and autumn (Hansen et al. 1999, Madsen et al. 2008, S. ZamoraTerol et al. unpubl.). However, 2010 was a historically warm year in Greenland (Jensen \& Rasch 2011), which could result in an early initiation of the high productive period. Periods of low productivity are rarely included in studies of copepod life history; in that sense, our study is unique because it included the pre-bloom population dynamics of $O$. similis, thereby improving our knowledge on the ecology of this copepod in the period of the year when it dominates the plankton community.

\section{Feeding rates and prey selection}

In all of the feeding experiments carried out in the present study, Oithona similis had a clear preference for medium-sized ciliates (20 to $40 \mu \mathrm{m}$ ). Preference for ciliates has been reported from ecosystems at lower latitudes, not only for O. similis (Nakamura \& Turner 1997, Castellani et al. 2005a) but also for other Oithona species (Atienza et al. 2006: O. nana, S. Za- 
mora-Terol et al. unpubl.: O. attenuata). Experiments with $O$. similis feeding on natural plankton populations demonstrated that when dinoflagellates were as abundant as ciliates, O. similis still preferred ciliates (Nakamura \& Turner 1997, Castellani et al. 2005a), confirming the pattern observed in the present study and suggesting the active selection for ciliates by Oithona spp. In this context, our grazing rates of O. similis on dinoflagellates were controversial throughout the different experiments. We observed no significant ingestion ( $t$-test, $\mathrm{p}>0.05$ ) in most of the experiments conducted, occasionally resulting in negative clearance values in some replicates, probably as a consequence of trophic cascade effects. Therefore, we cannot rule out that $O$. similis grazed on dinoflagellates, but in any case, predation on ciliates seemed to be more important.

As expected, we found no ingestion of diatoms, in agreement with most previous studies (Uchima 1988, Lischka \& Hagen 2007, Nishibe et al. 2010). Although reports on diatom consumption by Oithona spp. can occasionally be found in the literature (Lampitt \& Gamble 1982, Atkinson 1996, Atienza et al. 2006, Pond \& Ward 2011), it is not clear what mechanisms are involved. Svensen \& Kiørboe (2000) suggest that ambush raptorial copepods such as Oithona similis rely on hydromechanical signals for detecting individual prey, and Kiørboe \& Visser (1999) further showed that the hydromechanical signals from nonmotile and slow-sinking particles are below the detection threshold of $O$. similis.

In the case of size preference, there are also different opinions on the capability of Oithona spp. to feed on very small or large prey. We did not check the ingestion of small flagellates $(<5 \mu \mathrm{m})$, but we observed that small $(<5$ to $10 \mu \mathrm{m})$ single diatoms were not ingested in any of the experiments. In the present study, Oithona similis captured particles mainly within the 10 to $40 \mu \mathrm{m}$ size range, in agreement with previous investigations on the same species (Drits \& Semenova 1984, Castellani et al. 2005a, Nishibe et al. 2010); however, a wider range of sizes has also been reported (4 to $300 \mu \mathrm{m}$ ) for O. nana (Lampitt \& Gamble 1982). It is very likely that in natural environments, size preferences will be influenced by the abundance and type of prey comprised in that range, in particular Strombidium-like and Strobilidium-like ciliates.

Daily rations ( $\%$ body $\mathrm{C}$ ingested $\mathrm{d}^{-1}$ ) of Oithona similis found in the present study were positively correlated with the abundance of ciliates and were on average $1.4 \%$ in winter, $16 \%$ during the spring bloom, and $6 \%$ in the post-bloom. Assuming that metabolic costs would account for $1.4 \% \mathrm{~d}^{-1}$ (at $4{ }^{\circ} \mathrm{C}$;
Castellani et al. 2005b), the ingestion rates measured in spring were more than enough to cover respiration costs at the mean temperature encountered in Disko Bay. For the winter period, however, ingestion rates were rather low and only occasionally could be sufficient to cover metabolic requirements, suggesting the need to use lipid reserves to ensure the winter survival of $O$. similis (Narcy et al. 2009). In contrast to large calanoid copepods that go into diapause, during the winter, $O$. similis appears to be actively feeding and reproducing (see 'Egg production rates and efficiency'), even if at low rates, despite the low temperatures and nutritionally diluted environment.

\section{Egg production rates and efficiency}

Overall, the fecundity of Oithona similis in the present study did not respond strongly to the development of the spring bloom and associated microbial community (Fig. 9A,B), and it was only during the post-bloom that a substantial increase in egg production occurred.

The proportion of ovigerous females found here (8 to $56 \%$ ) was in the range of reported values in other high-latitude environments (e.g. 0 to $67 \%$ reported by Ward \& Hirst [2007] and 22 to $52 \%$ by Dvoretsky \& Dvoretsky [2009b]). The maximum percentage of ovigerous females (56\%) was observed at the end of May (post-bloom) and was close to the maximum values reported for $O$. similis in the Southern Ocean (67\%; Ward \& Hirst 2007). The presence of ovigerous females in winter also suggests they are reproductively active throughout the year, as previously reported in other polar environments (Fransz \& Gonzalez 1995, Metz 1995, Lischka \& Hagen 2005)

Clutch sizes found for Oithona similis were within the range reported in the literature (18 to 26 eggs per female; Castellani et al. 2007, Dvoretsky \& Dvoretsky 2009a). Despite the changes in food availability throughout the study period, clutch size did not vary much (16 to 24 eggs female ${ }^{-1}$ ), in agreement with previous studies that also reported little variation throughout the year (Danish coastal waters: Kiørboe \& Nielsen 1994; Barents Sea: Dvoretsky \& Dvoretsky 2009a; Southwest Atlantic: Temperoni et al. 2011). We could not find a correlation between clutch size and food availability (Fig. 9A) or any other factors, suggesting that clutch size is weakly dependent on environmental factors. Egg production rates in the present study ( 0.1 to 0.9 eggs female ${ }^{-1} \mathrm{~d}^{-1}$ ) are within the range of the lowest values reported in earlier 

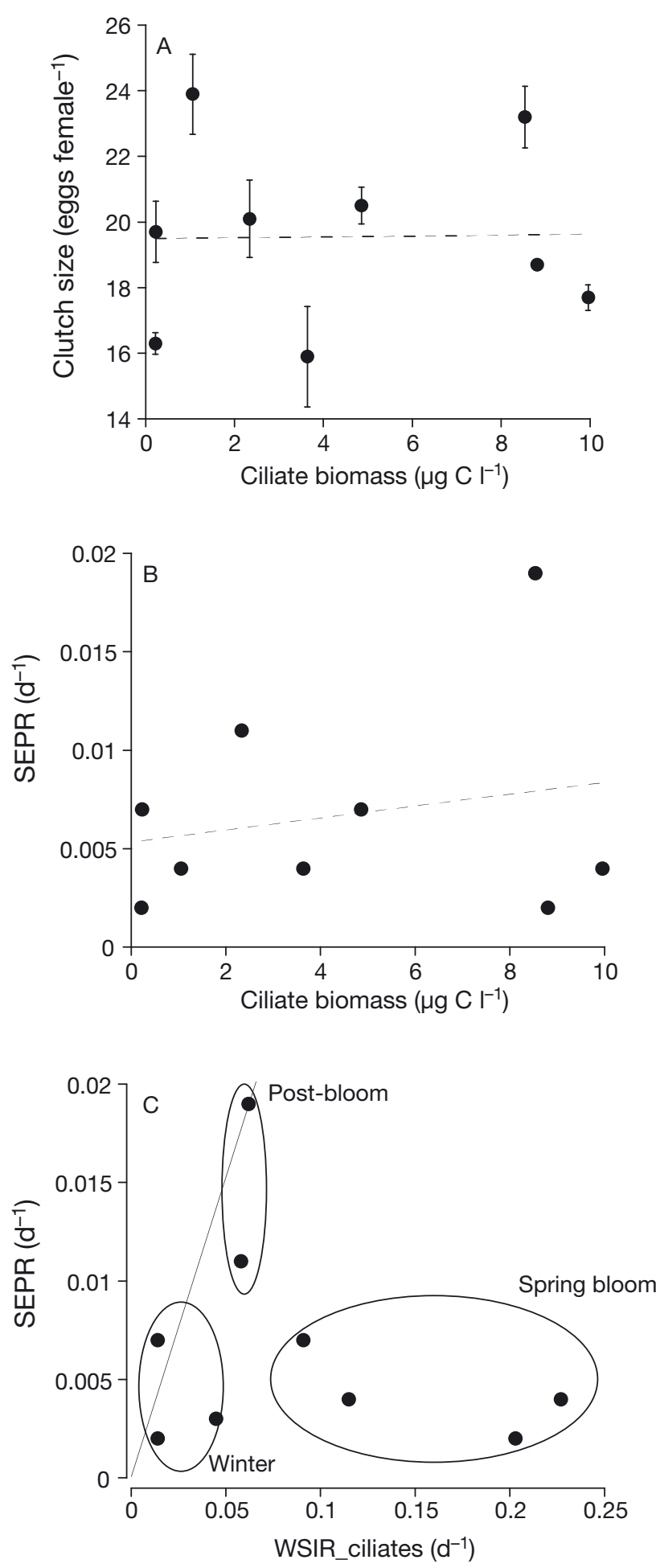

Fig. 9. Oithona similis adult females. (A) Clutch size (eggs female $^{-1}$ ) and (B) weight-specific egg production rates $\left(\mathrm{SEPR}_{i} \%, \mathrm{~d}^{-1}\right)$ plotted against the average biomass of ciliates $\left(\mu \mathrm{C} \mathrm{C}^{-1}\right)$; dashed lines show linear regressions. (C) Weightspecific egg production rate (SEPR) plotted against weightspecific ingestion rate (WSIR) on ciliates. Continuous line indicates $30 \%$ of egg production efficiency (i.e. GGE) studies on the same species from lower (Castellani et al. 2005a, Ward \& Hirst 2007) and similar (Dvoretsky \& Dvoretsky 2009b) latitudes.

Egg production rates are influenced by different factors, and food availability has been considered one of the most important factors driving feeding and egg production rates for calanoid copepods (Kiørboe \& Nielsen 1994, Saiz \& Calbet 2011). We did not find any clear relationship between food availability and any reproductive parameter of Oithona similis. In fact, average egg production rates were the same in winter and during the spring bloom, 0.2 eggs female ${ }^{-1} \mathrm{~d}^{-1}$. However, an increase of the egg production ( 0.5 to 0.9 eggs female ${ }^{-1} \mathrm{~d}^{-1}$ ) was observed during the post-bloom phase, very likely due to a delay between coupling of food availability (which increased during the spring bloom) and fecundity. These observations are in agreement with studies that covered a longer part of the reproductive season for $O$. similis and that reported reproductive peaks in summer or early autumn (Lischka \& Hagen 2007, Madsen et al. 2008, Dvoretsky \& Dvoretsky 2009a). In this regard, we should not ignore temperature as an important factor controlling the egg production of Oithona spp. Maximum egg production rates in eggcarrying copepods are greatly determined by hatching times, which are at the same time dictated by temperature (McLaren 1965, Nielsen et al. 2002). Studies of the egg production of Oithona spp. have described the strong effect of water temperature on hatching times and egg production rates (Sabatini \& Kiørboe 1994, Uye \& Sano 1995, Drif et al. 2010), as has also been documented in calanoid copepods (see Mauchline 1998).

Weight-specific egg-production rates reported in the present study for Oithona similis $\left(0.2\right.$ to $\left.2 \% \mathrm{~d}^{-1}\right)$ are in agreement with previous investigations on the same species $\left(0\right.$ to $2 \% \mathrm{~d}^{-1}$ reported by Ward \& Hirst [2007] and 0.5 to $4 \% \mathrm{~d}^{-1}$ by Dvoretsky \& Dvoretsky [2009b]) and are slightly higher than values found for Oithona spp. in the same area during the same time of the year $\left(0.004\right.$ to $1.5 \% \mathrm{~d}^{-1}$; Madsen et al. 2008). In general, our maximum weight-specific eggproduction rates are in good agreement with previous studies in high-latitude environments at temperatures similar to ours (Ward \& Hirst 2007, Dvoretsky \& Dvoretsky 2009b).

Surprisingly, we found that the egg-production efficiency (i.e. GGE) was high during winter and very low during the spring bloom (Table 4). As mentioned above, it is very likely that females of Oithona similis were using lipid reserves in winter to compensate for the low food concentration, and 
these reserves contributed to fuel egg production. In this regard, it has been observed that $O$. similis exhibits low content of lipids in spring in the Arctic (Lischka \& Hagen 2007). This fact would explain that the high feeding rates in spring do not translate into high egg production but are very likely allocated to refuel the lipid reserves. Although some studies have investigated reproduction of $O$. similis, very few have compared feeding with egg production and calculated their growth efficiencies (Castellani et al. 2005a). The egg production efficiency (i.e. GGE) found in the present study was on average $15 \%$, whereas Castellani et al. (2005a) reported $47 \%$ in the North Atlantic. Difference in estimations could be due to the use of egg-production rates calculated from the population instead of measurements of individual females. The GGE found in the present study was in good agreement with the value estimated in the laboratory for O. davisae (16\%) based on individual female incubations (ZamoraTerol \& Saiz 2013).

In this study, we have documented how Oithona similis actively feeds and successfully reproduces during winter. We have also confirmed the preference of Oithona spp. for ciliates as prey items, highlighting their key role in pelagic food webs as a link between the microbial food web and higher trophic levels. This role is especially relevant in Arctic and subarctic plankton webs when larger Calanus spp. are not active in the water column. In conclusion, the capability of Oithona spp. to survive and succeed when conditions in the water are unfavourable might explain the success of the genus not only in polar environments but also in marine environments worldwide.

Acknowledgements. We thank the Greenland Institute of Natural Resources in Nuuk for excellent laboratory facilities, K. Arendt for helping with laboratory logistics, and F. Heinrich for helping on board the boat 'Erisaalik' during the samplings in Godthåbsfjord. We also thank the Arctic station in Qeqertarsuaq (University of Copenhagen) for providing an excellent working platform and ship time, and the crew of the RV 'Porsild' for enthusiastic help during sampling. We also thank N. Lundholm for her advice on diatom and protozooplankton identification. This research was funded by the Greenland Climate Research Centre through the project 6505 to T.G.N. and the European Commission FP7 EURO-BASIN (grant agreement: 264 933). The Spanish Ministry of Economy and Competitiveness supported this work through the projects CTM2007-60052, CTM2010-10036-E, and CTM2011-23480 to E.S. (2009SGR-1283) and a PhD fellowship (BES-2008004231) and mobility grant to S.Z.T. We thank J. Turner for English editing and 2 anonymous reviewers for their positive comments on the manuscript.

\section{LITERATURE CITED}

Arendt KE, Nielsen TG, Rysgaard S, Tönnesson K (2010) Differences in plankton community structure along the Godthåbsfjord, from the Greenland Ice Sheet to offshore waters. Mar Ecol Prog Ser 401:49-62

Atienza D, Calbet A, Saiz E, Alcaraz M, Trepat I (2006) Trophic impact, metabolism, and biogeochemical role of the marine cladoceran Penilia avirostris and the codominant copepod Oithona nana in NW Mediterranean coastal waters. Mar Biol 150:221-235

Atkinson A (1996) Subantarctic copepods in an oceanic, low chlorophyll environment: ciliate predation, food selectivity and impact on prey populations. Mar Ecol Prog Ser 130:85-96

Auel H, Hagen W (2002) Mesozooplankton community structure, abundance and biomass in the central Arctic Ocean. Mar Biol 140:1013-1021

Castellani C, Irigoien X, Harris RP, Lampitt RS (2005a) Feeding and egg production of Oithona similis in the North Atlantic. Mar Ecol Prog Ser 288:173-182

> Castellani C, Robinson C, Smith T, Lampitt RS (2005b) Temperature affects respiration rate of Oithona similis. Mar Ecol Prog Ser 285:129-135

> Castellani C, Irigoien X, Harris RP, Holliday NP (2007) Regional and temporal variation of Oithona spp. biomass, stage structure and productivity in the Irminger Sea, North Atlantic. J Plankton Res 29:1051-1070

Conover RJ (1988) Comparative life histories in the genera Calanus and Neocalanus in high latitudes of the northern hemisphere. Hydrobiologia 167-168:127-142

Conover RJ, Siferd TD (1993) Dark-season survival strategies of coastal zone zooplankton in the Canadian Arctic. Arctic 46:303-311

Drif K, Hirst AG, Hay S (2010) Seasonal abundance and egg production rates of Oithona similis and Pseudocalanus elongatus in the northern North Sea: a first comparison of egg-ratio and incubation methods. Mar Ecol Prog Ser 415:159-175

Drits AV, Semenova TN (1984) Experimental investigations on the feeding of Oithona similis, Claus. Oceanology (USSR) 24:755-759

> Dvoretsky V, Dvoretsky A (2009a) Life cycle of Oithona similis (Copepoda: Cyclopoida) in Kola Bay (Barents Sea). Mar Biol 156:1433-1446

> Dvoretsky VG, Dvoretsky AG (2009b) Spatial variations in reproductive characteristics of the small copepod Oithona similis in the Barents Sea. Mar Ecol Prog Ser 386:133-146

Edmondson WT (1971) Reproductive rates determined directly from egg ratio. In: Edmondson WT, Winberg GG (eds) A manual on methods for assessment of secondary production in fresh waters. Blackwell Scientific, Oxford, p 165-169

> Fransz HG, Gonzalez SR (1995) The production of Oithona similis (Copepoda: Cyclopoida) in the Southern Ocean. ICES J Mar Sci 52:549-555

> Frost BW (1972) Effects of size and concentration of food particles on the feeding behavior of the marine planktonic copepod Calanus pacificus. Limnol Oceanogr 17: 805-815

Gallienne CP, Robins DB (2001) Is Oithona the most important copepod in the world's oceans? J Plankton Res 23: 1421-1432

> Hansen BW, Nielsen TG, Levinsen H (1999) Plankton com- 
munity structure and carbon cycling on the western coast of Greenland during the stratified summer situation. III. Mesozooplankton. Aquat Microb Ecol 16:233-249

- Hansen FC, Mollmann C, Schutz U, Hinrichsen HH (2004) Spatio-temporal distribution of Oithona similis in the Bornholm Basin (Central Baltic Sea). J Plankton Res 26: 659-668

> Hansen MO, Nielsen TG, Stedmon CA, Munk P (2012) Oceanographic regime shift during 1997 in Disko Bay, Western Greenland. Limnol Oceanogr 57:634-644

- Haury LR, Yamazaki H, Itsweire EC (1990) Effects of turbulent shear flow on zooplankton distribution. Deep-Sea Res A 37:447-461

Head EJH, Harris LR, Yashayaev I (2003) Distributions of Calanus spp. and other mesozooplankton in the Labrador Sea in relation to hydrography in spring and summer 1995-2000. Prog Oceanogr 59:1-30

> Hillebrand H, Dürselen CD, Kirschtel D, Pollingher U, Zohary T (1999) Biovolume calculation for pelagic and benthic microalgae. J Phycol 35:403-424

> Hopcroft R, Clarke C, Nelson R, Raskoff K (2005) Zooplankton communities of the Arctic's Canada Basin: the contribution by smaller taxa. Polar Biol 28:198-206

Jensen LM, Rasch M (eds) (2011) Nuuk ecological research operations, 4th Annual Report, 2010. DCE - Danish Centre for Environment and Energy, Aarhus University

Kiørboe T, Nielsen TG (1994) Regulation of zooplankton biomass and production in a temperate, coastal ecosystem. I. Copepods. Limnol Oceanogr 39:493-507

Kiørboe T, Visser AW (1999) Predator and prey perception in copepods due to hydromechanical signals. Mar Ecol Prog Ser 179:81-95

Kiørboe T, Møhlenberg F, Hamburger K (1985) Bioenergetics of the planktonic copepod Acartia tonsa: relation between feeding, egg production and respiration, and composition of specific dynamic action. Mar Ecol Prog Ser 26:85-97

> Lampitt RS, Gamble JC (1982) Diet and respiration of the small planktonic marine copepod Oithona nana. Mar Biol 66:185-190

> Levinsen H, Nielsen TG, Hansen BW (2000) Annual succession of marine pelagic protozoans in Disko Bay, West Greenland, with emphasis on winter dynamics. Mar Ecol Prog Ser 206:119-134

> Lischka S, Hagen W (2005) Life histories of the copepods Pseudocalanus minutus, P. acuspes (Calanoida) and Oithona similis (Cyclopoida) in the Arctic Kongsfjorden (Svalbard). Polar Biol 28:910-921

Lischka S, Hagen W (2007) Seasonal lipid dynamics of the copepods Pseudocalanus minutus (Calanoida) and Oithona similis (Cyclopoida) in the Arctic Kongsfjorden (Svalbard). Mar Biol 150:443-454

> Lonsdale DJ, Caron DA, Dennett MR, Schaffner R (2000) Predation by Oithona spp. on protozooplankton in the Ross Sea, Antarctica. Deep-Sea Res II 47:3273-3283

> Madsen S, Nielsen T, Hansen B (2008) Annual population development and production by small copepods in Disko Bay, western Greenland. Mar Biol 155:63-77

Mauchline J (1998) The biology of calanoid copepods. Advances in Marine Biology, Vol 33. Academic Press, London

McLaren IA (1965) Some relationships between temperature and egg size, body size, development rate, and fecundity, of the copepod Pseudocalanus. Limnol Oceanogr 10:528-538
Menden-Deuer S, Lessard EJ (2000) Carbon to volume relationships for dinoflagellates, diatoms, and other protist plankton. Limnol Oceanogr 45:569-579

Metz C (1995) Seasonal variation in the distribution and abundance of Oithona and Oncaea species (Copepoda, Crustacea) in the southeastern Weddell Sea, Antarctica. Polar Biol 15:187-194

Møller EF, Nielsen TG, Richardson K (2006) The zooplankton community in the Greenland Sea: composition and role in carbon turnover. Deep-Sea Res I 53:76-93

Mortensen J, Lennert K, Bendtsen J, Rysgaard S (2011) Heat sources for glacial melt in a sub-Arctic fjord (Godthåbsfjord) in contact with the Greenland Ice Sheet. J Geophys Res 116:C01013

- Nakamura Y, Turner JT (1997) Predation and respiration by the small cyclopoid copepod Oithona similis: How important is feeding on ciliates and heterotrophic flagellates? J Plankton Res 19:1275-1288

Narcy F, Gasparini S, Falk-Petersen S, Mayzaud P (2009) Seasonal and individual variability of lipid reserves in Oithona similis (Cyclopoida) in an Arctic fjord. Polar Biol 32:233-242

> Nielsen TG, Andersen CM (2002) Plankton community structure and production along a freshwater-influenced Norwegian fjord system. Mar Biol 141:707-724

> Nielsen TG, Sabatini M (1996) Role of cyclopoid copepods Oithona spp. in North Sea plankton communities. Mar Ecol Prog Ser 139:79-93

> Nielsen TG, Møller EF, Satapoomin S, Ringuette M, Hopcroft RR (2002) Egg hatching rate of the cyclopoid copepod Oithona similis in arctic and temperate waters. Mar Ecol Prog Ser 236:301-306

> Nishibe Y, Kobari T, Ota T (2010) Feeding by the cyclopoid copepod Oithona similis on the microplankton assemblage in the Oyashio region during spring. Plankton Benthos Res 5:74-78

Olenina I, Hajdu S, Edler L, Andersson A and others (2006) Biovolumes and size-classes of phytoplankton in the Baltic Sea. HELCOM BaltSea Environ Proc No 106

$>$ Paffenhöfer GA (1993) On the ecology of marine cyclopoid copepods (Crustacea, Copepoda). J Plankton Res 15: 37-55

> Pond DW, Ward P (2011) Importance of diatoms for Oithona in Antarctic waters. J Plankton Res 33:105-118

> Sabatini M, Kiørboe T (1994) Egg production, growth and development of the cyclopoid copepod Oithona similis. J Plankton Res 16:1329-1351

- Saiz E, Calbet A (2011) Copepod feeding in the ocean: scaling patterns, composition of their diet and the bias of estimates due to microzooplankton grazing during incubations. Hydrobiologia 666:181-196

> Saiz E, Calbet A, Isari S, Antó M and others (2013) Zooplankton distribution and feeding in the Artic Ocean during a Phaeocystis pouchetii bloom. Deep-Sea Res I 72:17-33

Svensen C, Kiørboe T (2000) Remote prey detection in Oithona similis: hydromechanical versus chemical cues. J Plankton Res 22:1155-1166

Svensen C, Seuthe L, Vasilyeva Y, Pasternak A, Hansen E (2011) Zooplankton distribution across Fram Strait in autumn: Are small copepods and protozooplankton important? Prog Oceanogr 91:534-544

Tang KW, Nielsen TG, Munk P, Mortensen J and others (2011) Metazooplankton community structure, feeding rate estimates, and hydrography in a meltwater- 
influenced Greenlandic fjord. Mar Ecol Prog Ser 434: $77-90$

Temperoni B, Viñas MD, Diovisalvi N, Negri R (2011) Seasonal production of Oithona nana Giesbrecht, 1893 (Copepoda: Cyclopoida) in temperate coastal waters off Argentina. J Plankton Res 33:729-740

Thor P, Nielsen TG, Tiselius P, Juul-Pedersen T and others (2005) Post-spring bloom community structure of pelagic copepods in the Disko Bay, Western Greenland. J Plankton Res 27:341-356

Uchima M (1988) Gut content analysis of neritic copepods Acartia omorii and Oithona davisae by a new method.

Editorial responsibility: Anna Pasternak,

Moscow, Russian Federation
Mar Ecol Prog Ser 48:93-97

Uye S, Sano K (1995) Seasonal reproductive biology of the small cyclopoid copepod Oithona davisae in a temperate eutrophic inlet. Mar Ecol Prog Ser 118:121-128

Ward P, Hirst A (2007) Oithona similis in a high latitude ecosystem: abundance, distribution and temperature limitation of fecundity rates in a sac spawning copepod. Mar Biol 151:1099-1110

Zamora-Terol S, Saiz E (2013) Effects of food concentration on egg production and feeding rates of the cyclopoid copepod Oithona davisae. Limnol Oceanogr 58: 376-387

Submitted: October 23, 2012; Accepted: January 24, 2013 Proofs received from author(s): April 29, 2013 